\title{
EFFECT OF REPLACING FISH MEAL WITH LIZARD MEAT MEAL ON DIETS FED TO AFRICAN GIANT LAND SNAIL (ARCHACHATINA MARGINATA)
}

\author{
Ugwuowo L.C., ${ }^{1}$ Ezeano C. I., ${ }^{2}$ Osita C., ${ }^{3}$ Chukwuemeka P. I ${ }^{1}$ \\ 1 Department of Animal Science, Nnamdi Azikiwe University Awka, Anambra State, Nigeria \\ ${ }^{2}$ Department of Agricultural Economics and Extension, Nnamdi Azikiwe University Awka, Anambra State, Nigeria \\ ${ }^{3}$ Department of Animal Science, University of Nigeria Nsukka \\ *Corresponding Author Email: chidilu2002@yahoo.com
}

This is an open access article distributed under the Creative Commons Attribution License, which permits unrestricted use, distribution, and reproduction in any medium, provided the original work is properly cited.

\section{ARTICLE DETAILS}

\section{Article History:}

Received 20 November 2018 Accepted 25 December2018 Available online 28 January 2019

\section{ABSTRACT}

The study was conducted to evaluate the growth performance of Archachatina marginata snails fed diets containing fish meal replaced at various levels with lizard meat meal. One hundred and twenty snails with similar weights were used for the study which lasted for 56 days. The snails were randomly assigned to four treatments and each treatment was replicated three times with 10 snails per replicate. Four experimental diets were formulated with various inclusion levels of lizard meat meal. Treatment 1 diet had 0\% replacement level, Treatment 2 diet had 15\% replacement level, Treatment 3 diet had 30\% replacement level and Treatment 4 diet had $45 \%$ replacement level. The data collected was analyzed using one-way analysis of variance and Duncan Multiple Range Test for significant means separation. The result of the experiment showed that there were no significant differences $(\mathrm{P}>0.05)$ in feed intake, weight gain, feed conversion ratio, shell characteristics (shell length, shell circumference and shell aperture increment) and cost of feed per kg weight gain between treatments. The result showed that there was significant difference $(\mathrm{p}<0.05)$ in shell thickness between treatments. The results of the experiment suggest that lizard meat meal can be used to replace fish meal in diets fed to Archachatina marginata snails up till $45 \%$ replacement level.

\section{KEYWORDS}

Archachatina marginata, fish meal, lizard meat meal, replacement, levels

\section{INTRODUCTION}

Livestock production is a major component of Agricultural Industry and much effort is being directed towards improving this sector. One of the areas in agricultural production which needs to be developed is snail farming. Snail meat contains high level of protein, iron and amino acids needed by man for proper growth and development. It is low in cholesterol and commands high demand. Archachatina marginata can grow up to $20 \mathrm{~cm}$ long and live for years. The specie spread mainly in the coastal region of West Africa. The natural spread of this specie is very slow but individuals who source it for use as food and as medicine spread it unintentionally. The population of African giant land snail in the world is increasingly reduced by hunting and deforestation that destroys their habitat [1, 2]. Rearing of Archachatina marginata as a domestic animal would therefore help in some measure to satisfy the demand for snail meat and also ensure the survival of the specie.

One of the major problems facing rearing of snail is formulating an improved diet that can meet their nutrient requirements. The provision of compounded diet has richly enhanced the growth performance of Mollusc particularly when the feed ingredients are specially formulated towards achieving their nutritional requirements. Some researchers pointed out the need to use complete diet in snail production $[3,4]$.

The inclusion of protein source like fish meal in snail diet which is one of the important feed stuffs in snail feed is costly and sometimes unavailable and that is why other sources of protein like lizard meat meal is introduced to know if they can substitute fish meal in snail diets. In a study reported protein content of $54.05-57.69 \%$ in Agama Lizard [5]. This study therefore is to know the growth performance of African giant snail (Archachatina Marginata) fed diet containing lizard meat meal at 0, 15, 30 and $45 \%$ replacement levels for fish meal.

\section{MATERIALS AND METHOD}

\subsection{Study Site and Duration of Study}

The study was carried out at the Snailery Unit of the Department of Animal Science and Technology, Nnamdi Azikiwe University Awka, Anambra State. The Snailery unit is surrounded by permanent trees. The Unit was constructed in such a way that there is free air movement. The experiment lasted for 2 months (8 weeks).

\subsection{Preparation of lizard meat meal}

Lizard meat meal was the test ingredient used to formulate the diets. The lizard meat was hunted from the bush in Amansea village in Anambra State. The lizard meat was oven dried and grinded before including it in the experimental diets. 


\subsection{Experimental Animal}

One hundred and twenty grower African giant land snails (Archachatina marginata) were used for the experiment. The snails were bought from Onitsha market.

\subsection{Experimental Diets}

Lizard meat meal was included to replace fish meal at 0, 15, 30 and $45 \%$ to form T1, T2, T3 and T4 diets respectively. Table 1 shows the composition of the experimental diets.

Table 1: Gross composition of the experimental diets

\begin{tabular}{|c|c|c|c|c|}
\hline \multirow[t]{2}{*}{ Ingredients(kg) } & \multirow{2}{*}{$\begin{array}{l}\text { Treatment } \\
\text { T1 }\end{array}$} & \multicolumn{3}{|l|}{ diets } \\
\hline & & $\mathrm{T} 2$ & T3 & T4 \\
\hline Maize & 21.25 & 24.25 & 27.75 & 26.5 \\
\hline Cassava meal & 13 & 11 & 8 & 9 \\
\hline SBM & 26 & 25 & 24 & 24.75 \\
\hline GNC & 13 & 13 & 13.5 & 13 \\
\hline Fish Meal & 5 & 4.25 & 3.5 & 2.75 \\
\hline $\begin{array}{l}\text { Lizard meat } \\
\text { meal }\end{array}$ & - & 0.75 & 1.5 & 2.25 \\
\hline Wheat Offal & 10 & 10 & 10 & 10 \\
\hline PKC & 3 & 3 & 3 & 3 \\
\hline Lime Stone & 3 & 3 & 3 & 3 \\
\hline Bone Meal & 5 & 5 & 5 & 5 \\
\hline Lysine & 0.25 & 0.25 & 0.25 & 0.25 \\
\hline Methionine & 0.25 & 0.25 & 0.25 & 0.25 \\
\hline Vitamins & 0.25 & 0.25 & 0.25 & 0.25 \\
\hline /Premix & & & & \\
\hline Crude Protein & 24.06 & 24.02 & 24.00 & 24.01 \\
\hline
\end{tabular}

\subsection{Experimental Design}

A total of 30 snails were randomly allocated to each of the four treatments. Each of the experimental unit had three (3) replicates designated as R1, R2 and R3. The replicates contained 10 young snails each. The experimental design was completely randomized design with four treatment and three replicates as presented below.

Table 2: Experimental lay out

\begin{tabular}{llll}
\hline Treatment 1 & Treatment 2 & Treatment 3 & Treatment 4 \\
30 Snails & 30 Snails & 30 Snails & 30 Snails \\
$\mathrm{R} 1=10$ snail & $\mathrm{R} 1=10$ snail & $\mathrm{R} 1=10$ snail & $\mathrm{R} 1=10$ snail \\
$\mathrm{R} 2=10$ snail & $\mathrm{R} 2=10$ snail & $\mathrm{R} 2=10$ snail & $\mathrm{R} 2=10$ snail \\
$\mathrm{R} 3=10$ snail & $\mathrm{R} 3=10$ snail & $\mathrm{R} 3=10$ snail & $\mathrm{R} 3=10$ snail \\
\hline
\end{tabular}

\subsection{Management of the experimental animal}

Plastic bowls were used to house the snails. These bowls were covered with mosquito nets to prevent the snails from crawling out. Uniform humidity was maintained within the house. The plastic bowl was filled with about $10 \mathrm{~cm}$ of heated loamy soil. The soil was pulverized after the removal of the snail feaces on daily bases.

\subsection{Feeding}

Feed was served to the snails once per day on flat plastic feeders. Water was also served to them using flat plastic watering trough.

\subsection{Data and Parameters Measured}

Shell Length and Shell Width were measured using vernier caliper on weekly basis.

Body weights were measured on weekly basis while Feed Intake was measured daily using sensitive weighing balance. The initial and final shell thicknesses were measured using micro meter screw gauge.

\subsection{Mortality}

No mortality was recorded.

\subsection{Feed conversion ratio (FCR)}

This was calculated as the ratio of feed consumed by the snails to the weight gained by the snails within the same period of time.

\subsection{Statistical Analysis}

The data collected were subjected to analysis of variance (ANOVA) using SPSS computer software package at 0.05 significant levels. Separation of significant means were done using Duncan's New multiple Range Test [6].

\section{RESULT AND DISCUSSION}

\subsection{Proximate analysis of the experimental diets}

The proximate analysis of the experimental diets is presented in table 3 . The proximate analysis shows that the experimental diets contained almost the same crude protein and energy values. The nutrients contained in the experimental diets were almost the same which shows that the snails were fed with isocaloric and isonitrogenous diets.

Table 3: Proximate analysis of the experimental diets

\begin{tabular}{|c|c|c|c|c|}
\hline \multicolumn{5}{|l|}{ Nutrients } \\
\hline & Treatment & Treatment & Treatment & Treatment \\
\hline & 1 & 2 & 3 & 4 \\
\hline $\begin{array}{l}\text { Dry } \\
\text { matter } \\
(\%)\end{array}$ & 90.52 & 90.38 & 92.21 & 92.42 \\
\hline $\begin{array}{l}\text { Moisture } \\
(\%)\end{array}$ & 9.48 & 8.62 & 7.79 & 7.58 \\
\hline Ash (\%) & 10.88 & 10.06 & 11.79 & 12.17 \\
\hline Crude & 23.63 & 23.42 & 23.31 & 22.94 \\
\hline $\begin{array}{l}\text { Protein } \\
(\%)\end{array}$ & & & & \\
\hline $\begin{array}{l}\text { Ether } \\
\text { Extract } \\
(\%)\end{array}$ & 1.25 & 1.35 & 2.48 & 2.95 \\
\hline $\begin{array}{l}\text { Crude } \\
\text { Fiber (\%) }\end{array}$ & 4.20 & 4.34 & 4.46 & 5.55 \\
\hline $\begin{array}{l}\text { Nitrogen } \\
\text { Free } \\
\text { Extract } \\
(\%)\end{array}$ & 50.56 & 51.21 & 52.17 & 52.81 \\
\hline $\begin{array}{l}\text { Gross } \\
\text { Energy } \\
\text { (kcal/kg) }\end{array}$ & 2991.74 & 2985.57 & 3004.64 & 3186.22 \\
\hline
\end{tabular}

\subsection{Proximate Composition of Lizard Meat Meal}

Table 4 shows the proximate composition of lizard meat meal. The table shows that the lizard meat meal used has $54.5 \%$ crude protein and contains nutrients which might make it useful as feed ingredient for snails. This nutrient composition shows that lizard meat meal can be used as feed ingredient for snails. This is in line with what reported about the proximate composition of lizard meat meal [7].

Table 4: Proximate Composition of the Lizard Meat Meal

\begin{tabular}{ll}
\hline Nutrients & \% Composition \\
Dry matter (\%) & 89.68 \\
Moisture (\%) & 10.32 \\
Ash (\%) & 9.57 \\
Crude Protein (\%) & 54.50 \\
Ether Extract (\%) & 2.56 \\
Crude Fiber (\%) & 1.11 \\
Nitrogen Free Extract (\%) & 21.94 \\
\hline
\end{tabular}




\subsection{Mineral Composition of Lizard Meat Meal}

Table 5 shows the mineral composition of lizard meat meal. The result showed that lizard meat contains 10 minerals. These minerals are needed by snails for proper growth and development. It shows a high composition of calcium which is one of the main minerals needed by snails for shell development and egg shell formation.

Table 5: Mineral Composition of Lizard Meat Meal

\begin{tabular}{ll}
\hline Minerals & \% Composition \\
Magnesium & 4.42 \\
Calcium & 555.70 \\
Chromium & 2.49 \\
Cobalt & 3.90 \\
Potassium & 522.67 \\
Iron & 70.08 \\
Zinc & 5.43 \\
Copper & 1.31 \\
Magnesium & 4.02 \\
Sodium & 574.50 \\
\hline
\end{tabular}

\subsection{Amino Acid Profile of Lizard Meat Meal}

The amino acid profile of lizard meat meal is shown in table 6. The result showed that lizard meat meal contains 14 amino acids which are lysine, threonine, cysteine, valine, methionine, iso-leucine, leucine, tyrosine, phenylalanine, histidine, arginine, alanine, glycine and aspartic acid. This corresponds reported about the amino acid profile of lizard meat meal [7].

Table 6: Amino Acid Profile of Lizard Meat Meal

\begin{tabular}{ll}
\hline Amino acid & \% Composition \\
Lysine & 4.10 \\
Threonine & 3.81 \\
Cysteine & 0.47 \\
Valine & 4.92 \\
Methionine & 1.00 \\
Iso-leucine & 3.63 \\
Leucine & 9.64 \\
Tyrosine & 3.45 \\
Phenylalanine & 5.45 \\
Histidine & 2.31 \\
Arginine & 4.68 \\
Alanine & 4.11 \\
Glycine & 3.25 \\
Aspartic acid & 8.30 \\
\hline
\end{tabular}

3.5 Effect of varying inclusion levels of lizard meat meal on the growth performance of Archachatina marginata snails

Table 6 shows that there were no significant differences $(p>0.05)$ on the growth parameters of snails fed the experimental diet. The table shows that Treatment 2 with $15 \%$ inclusion had the highest weight gain while treatment 3 with $30 \%$ inclusion had the lowest weight gain. It also shows that treatment 2 with $15 \%$ inclusion consumed the highest quantity of feed while treatment 3 with $30 \%$ inclusion consumed the lowest quantity of feed. It can also be observed that treatment 3 with $30 \%$ inclusion had the highest feed conversion ratio while treatment 4 with $45 \%$ inclusion had the lowest feed conversion ratio. The result showed that there were no significant differences $(P>0.05)$ in the average initial weight of the experimental animals between treatments. This implies that the snails used for the experiment are of the same weight.

There was no significant differences $(\mathrm{P}>0.05)$ in the total weight gain between treatments. This shows that treatment 2 gained the highest weight during the experiment. The non-significance differences in the weight gain agrees with what Emelue and Omonzogbe, reported that there was no significant difference in the weight gain of Archachatina marginata snails fed feed formulated with different calcium sources [8]. It also agrees with what reported that there was no significant difference in the weight gain of Archachatina marginata snails fed diets containing soya bean meal residue-cassava sievate meal mixtures [9].

There was no significant difference $(P>0.05)$ in the total feed intake between treatments. The non-significance difference in the feed intake agrees reported that there was no significant difference in the daily feed intake of Archachatina marginata snails fed diets containing soya bean meal residue-cassava sievate meal mixtures [9]. This agrees with the theory that animals eat to meet up their energy requirements.

There was no significant difference $(\mathrm{P}<0.05)$ in feed conversion ratio between treatments. The non-significance difference in the feed conversion ratio corresponds reported that there was no significant difference in feed conversion ratio of Archachatina marginata snails fed diets containing soya bean meal residue-cassava sievate meal mixtures [9]. This implies that at $45 \%$ inclusion of lizard meat meal, the snails will consume less feed and gain more weight.

Table 7: Effect of varying inclusion levels of lizard meat meal on the growth performance of Archachatina marginata snails

\begin{tabular}{lllll}
\hline $\begin{array}{l}\text { Growth } \\
\text { Parameters }\end{array}$ & \multicolumn{2}{l}{ Dietary Treatments } \\
& $\begin{array}{l}\text { Treatment } \\
1(0 \%)\end{array}$ & $\begin{array}{l}\text { Treatment } \\
2(15 \%)\end{array}$ & $\begin{array}{l}\text { Treatment } \\
3(30 \%)\end{array}$ & $\begin{array}{l}\text { Treatment } \\
4(45 \%)\end{array}$ \\
$\begin{array}{l}\text { Average } \\
\text { initial } \\
\text { weight (g) }\end{array}$ & $42.83 \pm 1.69$ & $44.30 \pm 4.09$ & $44.70 \pm 4.30$ & $41.93 \pm 2.29$ \\
$\begin{array}{l}\text { Average } \\
\text { final }\end{array}$ & $50.03 \pm 1.75$ & $52.37 \pm 5.80$ & $50.53 \pm 4.52$ & $49.73 \pm 1.03$ \\
$\begin{array}{l}\text { weight(g) } \\
\text { Total } \\
\text { weight } \\
\text { gain(g) }\end{array}$ & $7.20 \pm 1.71$ & $8.07 \pm 1.72$ & $6.97 \pm 1.70$ & $7.87 \pm 1.93$ \\
$\begin{array}{l}\text { Average } \\
\text { daily }\end{array}$ & $0.13 \pm 0.03$ & $0.15 \pm 0.03$ & $0.12 \pm 0.03$ & $0.14 \pm 0.04$ \\
$\begin{array}{l}\text { weight } \\
\text { gain(g) }\end{array}$ & & & & \\
$\begin{array}{l}\text { Average } \\
\text { daily feed } \\
\text { intake(g) }\end{array}$ & $0.50 \pm 0.03$ & $0.54 \pm 0.04$ & $0.49 \pm 0.01$ & $0.52 \pm 51$ \\
$\begin{array}{l}\text { Total feed } \\
\text { intake(g) }\end{array}$ & $27.87 \pm 1.80$ & $30.33 \pm 2.20$ & $27.30 \pm 0.56$ & $29.37 \pm 2.93$ \\
$\begin{array}{l}\text { Feed } \\
\text { Conversion } \\
\text { Ratio }\end{array}$ & $4.00 \pm 0.90$ & $3.90 \pm 1.00$ & $4.10 \pm 09$ & $3.87 \pm 0.84$ \\
\hline
\end{tabular}

Means along rows with different superscript are significantly different $(\mathrm{P}<0.05)$

Table 8: Effect of varying inclusion levels of lizard meat meal on the shell characteristics of Archachatina marginata snails

\begin{tabular}{|c|c|c|c|c|}
\hline \multirow[t]{3}{*}{ Shell quality } & \multicolumn{4}{|c|}{ Dietary Treatments } \\
\hline & Treatment & Treatment & Treatment & Treatment \\
\hline & 1 & 2 & 3 & 4 \\
\hline $\begin{array}{l}\text { Shell length } \\
\text { increment }(\mathrm{cm}\end{array}$ & $0.06 \pm 0.03$ & $0.05 \pm 0.06$ & $0.05 \pm 0.05$ & $0.09 \pm 0.13$ \\
\hline $\begin{array}{l}\text { Shell } \\
\text { circumference } \\
\text { increment(cm } \\
\text { ) }\end{array}$ & $0.05 \pm 0.04$ & $0.04 \pm 0.01$ & $0.03 \pm 0.02$ & $0.01 \pm 0.01$ \\
\hline $\begin{array}{l}\text { Shell aperture } \\
\text { increment }(\mathrm{cm} \\
\text { ) }\end{array}$ & $0.53 \pm 0.70$ & $0.49 \pm 0.08$ & $0.52 \pm 0.20$ & $0.50 \pm 0.64$ \\
\hline $\begin{array}{l}\text { Shell thickness } \\
(\mathrm{mm})\end{array}$ & $\begin{array}{l}2.07 \pm 0.58 \\
\text { a }\end{array}$ & $\begin{array}{l}1.70 \pm 0.20 \\
\mathrm{a}\end{array}$ & $\begin{array}{l}0.32 \pm 0.29 \\
b\end{array}$ & $\begin{array}{l}1.86 \pm 0.08 \\
\text { a }\end{array}$ \\
\hline
\end{tabular}

Means along rows with different superscript are significantly different $(\mathrm{P}<0.05)$ 
Table 8 shows that there were no significant difference $(\mathrm{P}>0.05)$ in shell length increment, shell circumference increment and shell aperture increment between treatments. However, there was a significant difference $(\mathrm{P}<0.05)$ in shell thickness between treatments. The control diet had the highest shell thickness of $2.07 \pm 0.58 \mathrm{~mm}$ while treatment 3 with $30 \%$ inclusion had the lowest shell thickness of $0.32 \pm 0.29 \mathrm{~mm}$. The result showed no significant difference $(\mathrm{P}>0.05)$ in shell length increment between treatments. Treatment 4 had the highest shell length increment of $0.09 \pm 0.13 \mathrm{~cm}$ while Treatment 2 and 3 had the lowest shell length increment of $0.05 \pm 0.06 \mathrm{~cm}$. It also agrees with what reported that there was no significant difference in the shell length increment of Archachatina marginata snails fed diets containing soya bean meal residue-cassava sievate meal mixtures [9]. This report also agrees with what reported that there was no significant difference in the shell length increment and shell circumference increment of Archachatina marginata snails fed different proportions of leaves of Moringa oleifera and pawpaw [10]. The nonsignificance difference may be due to the uniform ash content of the experimental diets which contained the minerals responsible for shell formation.

There was no significant difference $(P>0.05)$ in shell circumference increment between treatments. Treatment 1 had the highest shell circumference increment of $0.05 \pm 0.04 \mathrm{~cm}$ while treatment 4 had the lowest shell circumference increment of $0.01 \pm 0.01$. This implies that as the level of inclusion of lizard meat meal increased, the shell circumference increment of Archachatina marginata snails also increased. The nonsignificance difference agrees with what reported that there was no significant difference in shell length increment and shell circumference increment of Archachatina marginata snails fed with feed formulated with different calcium sources [9]. It also agrees with who reported that there was no significant difference in shell circumference increment of Archachatina marginata snails fed diets containing soya bean meal residue-cassava sievate meal mixtures [9]. This is also in agreement with who reported that there were no significant differences in the shell length increment and shell circumference increment of Archachatina marginata snails fed different proportions of leaves of Moringa oleifera and pawpaw leaf meal [10].

The result showed no significant difference $(\mathrm{P}>0.05)$ in shell aperture increment between treatments. Treatment 1 had the highest shell aperture increment of $0.53 \pm 0.70 \mathrm{~cm}$ while treatment 2 had the lowest shell aperture increment of $0.49 \pm 0.08 \mathrm{~cm}$. The non-significance of the shell aperture increment may be due to the uniform ash content of the experimental diets.

The result showed a significant difference $(\mathrm{P}<0.05)$ between treatments on shell thickness. Treatment 1, 2 and 4 were significantly the same while Treatment 3 was statistically different from the other treatments. The significant difference agrees with reported that there was significant difference in the shell thickness of Archachatina marginata snails fed different proportions of leaves of Moringa oleifera and pawpaw leaf [10]. This suggests that the high level of calcium in lizard meat meal may have caused the significant difference in shell thickness of Archachatina marginata snails.

\subsection{Economic implication of feeding snails with varying inclusion levels of lizard meat meal}

The result shows no significant difference $(\mathrm{P}>0.05)$ in feed cost per $\mathrm{kg}$ weight gain. Table 9 shows that the cost of feed that can produce $1 \mathrm{~kg}$ flesh of snail was lowest in treatment 3 with $30 \%$ replacement level. Treatment 2 had the highest cost of feed per kg weight gain of \#19.72 while Treatment 3 had the lowest cost of feed per kg weight gain of \#17.95. It implies that a kg weight gain of snail meat was cheapest at $30 \%$ replacement level of lizard meat meal for Archachatina marginata snails. The result shows that treatment 3 diet had the lowest cost of \#4.39 while Treatment 2 diet had the highest cost of \#5.04. This implies that with increasing levels of inclusion of lizard meat meal, the cost of the feed slightly decreased.

Table 9: Economic implication of feeding snails with varying inclusion levels of lizard meat meal

\begin{tabular}{lllll}
\hline Parameters & \multicolumn{2}{l}{ Dietary Treatments } \\
& Treatment & Treatment & Treatment & Treatment \\
& 1 & 2 & 3 & 4 \\
$\begin{array}{l}\text { Cost of feed } \\
\text { intake (N) }\end{array}$ & $4.74 \pm 0.30$ & $5.04 \pm 0.37$ & $4.39 \pm 0.09$ & $4.71 \pm 0.47$ \\
$\begin{array}{l}\text { Feed cost } \\
\text { per kg }\end{array}$ & $19.00 \pm 4.67$ & $19.72 \pm 5.53$ & $17.95 \pm 4.47$ & $18.14 \pm 3.63$ \\
$\begin{array}{l}\text { weight gain } \\
\text { (N) }\end{array}$ & & & & \\
\hline
\end{tabular}

\section{CONCLUSION AND RECOMMENDATION}

According to the results, lizard meat meal can be used to replace fish meal even at $45 \%$ level of inclusion in the diet of Archachatina marginata snails since there were no significant differences in the growth parameters measured except in shell thickness. I therefore recommend that higher levels of replacement of fish meal with lizard meat meal should be tested to know if lizard meat meal can completely replace fish meal in diets fed to Archachatina marginata snails.

\section{REFERENCES}

[1] Ejidike, B.N. 2002. Snail Rearing Practices in Southern Nigeria. Proceedings of $27^{\text {th }}$ Annual Conference of the NSAP held in Akure. Pp. 307310.

[2] Agbogidi, O.M., Okonta, B.C., Ezeani, E.L. 2008. Effect of two edible fruits on the growth performance of African Giant Land Snail (Archachatina marginata). Journal of Agriculture and Biological Sciences, 3(3), 26-29.

[3] Omole, A.J., Tewe, 0.O., Makinde, G.O., Adeloro, F.O., Saka, J.O., Ogundola, I. 2002. Preliminary studies on the respond of growing snailsAfrican Giant Land Snail (Archachatina marginata) to compounded feed as a supplementary ratio. Tropical Animal Production Investigation, 3, 3540.

[4] Ejidike, B.N. 2001. Comparative effect of supplement and complete diets on the performance of African Giant Land Snail (Archachatina marginata). Proceedings of the $26^{\text {th }}$ Annual Conference of the Nigerian Society for Animal Production, 26, 151-153.

[5] Abulude, F.O., Adesanya, W.O., Ogunkoya, M.O., Onibon, V.O., Ajayi, E. 2007. Compositional studies on tropical species of Agama agama lizards.International Journal of Zoological Research, 3, 218-222.

[6] Duncan, D.B. 1955. New Multiple Range and Multiple F-tests. Biometrics, 11, 142

[7] Tiamiyu, L.O., Ataguba, G.A., Jimoh, J.O. 2013. Growth performance of Clarias gariepinus fishes fed different levels of Agama agama meal diet. Pakistan Journal of Nutrition, 12 (5), 510-515. ISSN: 1680-5194.

[8] Emelue, G.U., Omonzogbe, E.A. 2018. Growth performance of African Giant Land Snails (Archachatina marginata) fed with feed formulated with different calcium sources. Malaysian Journal of Sustainable Agriculture, 2 (1), 01-04.

[9] Ojebiyi, O.O., Jejelola, O.O., Oladunjoye, I.O., Shittu, M.D. 2011. Performance characteristics of African Giant Land Snail (Archachatina marginata) fed diets containing soya bean milk residue-cassava sievate meal mixtures. World J. Life Sci. and Medical Research, 1 (5), 105.

[10] Fayenuwo, J.O., Adekunle, O.F., Omole, A.J., Okpeze, C.N., Ajasin, F.O., Ononogbu, C. O. 2015. Growth and reproductive indices of growing snails fed different proportion of leaves of Moringa oleifera and paw. Proceeding of the $4^{\text {th }}$ international conference/workshop on giant African land snail. $1^{\text {st }} 4^{\text {th }}$ June, Pp. 155-158. 